\title{
A Critical Examination of Motivation in the Omani English Language Education System
}

\author{
Ali S.M. Al-Issa \\ Sultan Qaboos University, Muscat, Sultanate of Oman
}

\begin{abstract}
This study asks questions and elicits answers about the factors that influence E/FL motivation in the Sultanate of Oman from a critical perspective. It triangulates data from semi-structured interviews made with different informants involved in the Omani English language teaching (ELT) system and representing different social, cultural, and academic backgrounds, the Philosophy and Guidelines for the Omani English Language School Curriculum (Nunan, Walton, \& Tyacke, 1987) - herewith referred to as the National English Language Policy/Plan (NELP), the pertinent literature and the national textbook Our world Through English (OWTE). The critical discussion has revealed variable ideologies and statements about various factors influencing motivation for learning F/EL. The findings of this study have their direct and important implications for other similar F/EL planning and policy contexts.
\end{abstract}

Index Terms-ELT, NELP, OWTE, motivation, ideology

\section{ENGLISH IN OMAN}

English in the Sultanate of Oman is the only official foreign language. It has been receiving political, economic, and legislative support from the government, which has determined its place on the social hierarchy. It has institutional domains like the mass media, education, and business (Al-Busaidi, 1995). People in Oman learn English for several significant purposes like inter-lingual communication inland and abroad, conducting business, finding a white-collar job, pursuing higher education domestically or abroad, acquiring science and technology and analyzing and understanding the English language cultures. In their Philosophy and Guidelines for the Omani English Language School Curriculum document (Nunan, Walton, \& Tyacke, 1987) - herewith referred to as the National English Language Policy/Plan (NELP), the three authors describe English as central to Oman's continued national development and a pivotal tool for transition and "Omanization" - a process through which gradual replacement of expatriate manpower by Omani qualified and skilled working force occurs. The statistics revealed by the 2010 national census indicate that the number of the expatriate labor force has exceeded 800,000, bearing in mind that the overall population of Oman is about 2.9 million. Most of this relatively cheap workforce comes from countries like India, Pakistan, Bangladesh and the Philippines.

In spite of the importance of English as a powerful tool for achieving multiple purposes, students have always exited the Omani system with a poor functional level. Much of this is attributed to motivation, as a powerful factor that drives foreign language learning and success. This study, therefore, attempts to discuss the factors that influence E/FL motivation from an "ideological" perspective. A thorough survey of the literature on F/EL has revealed that no work discussing this issue from an ideological perspective has been carried out or published.

Within this context, the following research questions are asked:

1. What are the key discourses in NELP about the factors influencing motivation?

2. What discourses inform the views of the different informants involved in the Omani ELT system about factors influencing motivation and their role in them?

3. What ideologies inform the views of the different informants involved in the Omani ELT system about factors influencing motivation and their role in them?

4. What are the key discourses in Our World Through English (OWTE) about factors influencing motivation and the role of the teacher in it?

5. What is the role of the teacher in influencing motivation in OWTE?

\section{IDEOLOGICAL DiMENSION IN NELP}

Nunan et al. (1987) consider language as a "living entity" and not a fact-based school subject, which can be memorized for exam purposes. They consider language learning as a "complex, multifaceted, multifunctional entity" ( $p$. 2)

The authors of NELP believe that one of the goals of the Omani English curriculum should be "To assist students acquire the competence to use English as a vehicle for learning and communication within the classroom, and as a medium of interpersonal communication in situations outside the classroom" (p. 28). 
Nunan et al. also mention success and see that it is important that students are given tasks and meaningful activities that provoke cognitive challenge and promote problem solving and critical thinking to arouse the students' motivation and positively impact their attitudes about learning English. This should be coupled with making the "... system more accountable for student proficiency/less for achievement grades" (NELP, p. 9). They propose incorporating authentic materials, which provide "naturalistic samples" of contextualized language like "... books, magazines, newspapers, brochures, documents, signs, notices, films, television, slide, tape, radio, public announcement, lecture or written report etc." (p. 14), which facilitate carrying out "real world tasks" using the target language. It is interesting to see that computers (and the Internet) are missing from this list, which can be attributed to the fact that Nunan et al. wrote their document at a time when computers and the Internet were not largely used as a significant tool for supporting teaching enhancing learning in education in general and language education in specific.

It is, therefore, important that learners are clear about why they are learning English since this is very likely to have a strong impact on their motivation, attitudes and attainment. The three authors claim that "... there are instances in which the purposes for which the learners need to learn English are not clear" (p. 14). They also claim that English in Oman is "seen as 'subject' like any other, not as skill" (p. 9). Nunan et al. believe that this results from the students developing “... integrative rather than instrumental motivation" (p. 9). The development of integrative motivation is associated with the exam-based system implemented in Oman. Nunan et al. critique the assessment system in Oman and describe it as "traditional". They propose that "... focus should be on the extent to which the ability to carry out communicative tasks ... has been improved through instruction" (p. 25). In other words, the three authors are advocating "criterion-referenced tests" (p. 25), which help involve students in "... communication and cooperation, rather than competition" (p. 24).

However, assessment in Oman gives priority to mastery of content, which comes at the expense of comprehension and performance. Students in Oman take four monthly tests and two end-of-semester exams, except for the Grade 12 students, who take only two end-of-semester exams. Scores determine their success or otherwise. Those who fail more than two subjects repeat the year. Parents and the society value formal tests and the marks scored in tests and look at them as a reliable source of gauging their children's performance. The authors view this as lack of awareness on the part of the parents. They, therefore, propose involving parents and students more in " ... the understanding of curriculum objectives" (p. 9). They further suggest involving administrators, teachers and parents in a gradual awareness process to help influence the students' motivation. The writers of NELP additionally suggest that developing a system by which focus is on performance rather than on mastery of content can be help resolve the problem of perceptions toward examinations.

The writers of NELP, moreover, mention that students in Oman do not see English having functional relevance to their existence. The three authors believe that one of the reasons behind this is lack of resources and practice opportunities. Examples of resources provided by the team of writers are self-access resource centers, check-out audio cassettes and telecasting. They also suggest encouraging visits from various private companies like the Petroleum Development of Oman (PDO) and from public organizations like Sultan Qaboos University (SQU) - the only stateowned university in Oman, to “... show English as living, working part of Omani context” (p. 9).

Nunan et al. discuss the importance of educational technology through developing software to help reinforce the students' language skills and motivation beyond the classroom environment and provide extra opportunities for language interaction and train students to use language for cognitively challenging purposes like problem solving.

Furthermore, the writers of NELP promote exposure to the native speaker through various means other than direct verbal and physical contact with the native speaker. They mention films, TV and radio programs as important aspects of culture that can impact on the students' language proficiency.

In addition, Nunan et al. would like to see teachers as critical reflectors, needs analysts, competent language users and professionals, skilled, informed, confident, and autonomous decision makers, who can pick the right materials and design appropriate activities that arouse their students' integrative and intrinsic motivation, which the Omani education system seems to have overlooked, and foster and encourage meaningful language use to help bring about positive change to the system.

\section{ELT AND MOTIVATION}

Motivation is one of the most researched complex, critical, dynamic and forceful internal language development factors. Many authors have described it as a key factor and acknowledged and stressed its significance and centrality for successful foreign language learning. Gardner \& Lambert (1972), argue that motivation leads to increased effort and energy, enhances cognitive process, increases persistence in learning activities, and leads to improved performance.

Several authors have also linked positive attitudes about studying a foreign language and making effort to excel in it with strong motivation (Ellis, 1997, Gardner, 1985). High motivation has been also directly linked with a high desire to learn autonomously (Dahmardeh \& Hunt, 2012). Autonomous learning, in turn, has been highlighted as boosting student's confidence to overcome learning obstacles (Li \& Pan, 2009).

Motivation has been divided into "instrumental" and "integrative" (Gardner \& Lambert, 1972). While the former is associated with learning a foreign language for practical goals, the latter is associated with learning to become closer to the target language's communities, as it is the case the English language today. Motivation has been further classified 
into "intrinsic" and "extrinsic". While the former is associated with integrative orientation and learners are motivated to learn a foreign language for its own sake and the enjoyment it provides, the latter is commonly associated with instrumental orientation and the learner is mainly driven by some kind of external reward or fear of punishment, such as achieving better grades or receiving their teacher's approval.

Motivation has been perceived as a challenging issue facing teachers today (Dahmardeh \& Hunt, 2012). Humaida (2012) lists a number of factors that allow for the development of the student's motivation in English or foreign language learning. He mentions the home environment, school-related success and failure, teachers' performance, school-wide goals, classroom climate and policies and procedures. In addition, Brown (2007) lists the individual learner, teaching methodology, social interaction, cultural milieu and educational context as factors determining student's integrative and instrumental motivation. Moreover, Zhao (2012) discusses the teacher, activities and materials, relevance of content and instruction and the classroom environment as external factors affecting motivation. Baldauf (1990) thus places teachers at the heart of language education and values their professionalism. He views them as the sole interpreters of the syllabus that usually embraces and reflects the philosophies and ideologies set by the government, that resemble the close relationship between "... the use of language and power, socioeconomic development, national and local identity, and cultural values” (p. 18).

Petrides (2006) and Li and Pan (2009) suggest that use of communicatively popular and joyful activities play a crucial role in arousing students' motivation about learning English. Petrides (2006) considers students' active involvement in a task as a sign of motivation. Petrides discusses the importance of designing a variety of fun activities, new technologies, pictures, objects, signs, attractive visuals aids and the provision of opportunities to help the learners use the language for real life situations and for actual communication. This is in order to help them come across native speaker models either in real life (visits, teleconferencing and e-mails) or through the use of new technologies and available resources. Examples here can be web sites with authentic material. Petrised considers these as materials that can be used to promote motivation in ELT classroom. Costa (2011) suggests that “... the possible uses of technology in the classroom are endless" (p. 210). Shyamlee (2012) also argues that the " $21^{\text {st }}$ century is the age of globalization and is important to grasp on various foreign languages and English language comes first" (p. 151). Shyamlee adds that "technological innovations have gone hand in hand with the growth of English and are changing the way we communicate. It is fair to assert that the growth of the internet has facilitated the growth of the English language" (p. 151). Davies and Pearse (2000) and Al-Mamari (2007) thus consider the use of the Internet as positively impacting motivation and learner-centered teaching. Use of advanced technology, hence, is considered to help produce independent learners, who rely less on the teacher, while more on their ability and knowledge. The Internet, thus, has become a necessity in Oman rather than luxury. Almost every house in Muscat particularly has a computer or more and access to the Internet.

Kong (2009) thus stresses the responsibility of teachers as primary motivators of their students through using various and interesting activities, involving new and effective teaching techniques, high performance expectations, appropriate use of rewards, creation of a relaxed and positive learning climate inside the classroom, implementation of cooperative activities and provision of activities for students to experience success.

In an attempt to analyze the use of motivational strategies by English language teachers in Oman, Al-Mahrooqi, Abrar-Ul-Hassan and Cofie (2012) found that teachers in Oman overwhelmingly endorse motivation strategies related to the teacher's personal performance in the classroom. Those are promoting learner's self confidence, recognizing students' effort and celebrating their success, presenting tasks properly, making learning tasks stimulating, creating a pleasant and relaxed climate in the classroom, familiarizing learners with L2 related values, increasing learners' goalorientedness and promoting learner autonomy.

\section{Data Collection And Analysis}

The Omani situation under investigation is unique in itself. The aim of this study is thus to expand and generalize a theory and to suggest complexities for further future research, rather than provide statistical generalizations or enumerate frequencies. Multiple sources of evidence interviews - "critical" content analysis, written texts and documents, and the pertinent literature are used to make genuine contributions to the Omani context under investigation.

All these data sources encompass "ideologies" and "discourses" - two key concepts in this paper. Ideologies, as defined by van Dijk (1998) and within the context of this study mainly refer to systems of thoughts and conceptions of the world, and are general, abstract, collective, and socially and historically positioned, developed, produced and reproduced through communication and discourse. Gramsci (1971) views ideologies as articulated via discourses and produced by different social classes and are the result and the product of different social practices and history. Gee (1990) considers texts and discourses as rich sources through which knowledge, ideas, and beliefs about a particular notion are held and revealed, or a situation experienced by a particular person or a group of people.

The major source of data collection in this paper is the 15 informants involved in the Omani ELT system - teachers, inspectors, teacher trainers, school heads, SQU ELT faculty, English Language Curriculum Department (ELCD) officers, SQU Final Year ELT student teachers and Grade 12 students, who were selected on the basis of opportunity sampling technique. The reason for choosing Grade 12 students and SQU Final Year ELT student teachers is because their experience about learning English is longer due to having spent more years in the system. Certain criteria like 
gender, age and experience, were kept in mind when selecting the informants, who are all inhabitants of Muscat Area Oman's cosmopolitan capital to guarantee ideological diversity. Moreover, factors such as the informants' linguistic, academic, educational, cultural, and social backgrounds were taken into consideration for the aforementioned reason.

All agents received an interview protocol letter, which states the aim of this research and their role in it. They were further asked to fill out a descriptive information sheet, which requested different personal details pertinent to the study such as age, nationality, academic qualifications, present status, years spent in Oman, languages known and used most, place of and purpose behind learning English, and current use(s) of English. Their consent prior to conducting, taperecording, and transcribing the interviews was obtained.

All the agents in this study are directly or indirectly involved in ELT. Their diverse but direct and explicit systems of thoughts and conceptions of the world were reflected through their various discourses about ELT (see Table 1).

The three main questions which constructed the semi-structured interviews and aimed at eliciting the informants' statements about factors influencing motivation in E/FL are:

1. How did you learn English/a foreign language?

2. Why do you think some people learn English better and faster than others?

3. How do you consider English as a school subject within the Omani curriculum?

Other equally significant sources of data are NELP and the pertinent literature. These texts include variable sorts of information that can make a relevant source of data for this study. All these sources of data reveal knowledge, ideas, beliefs, and experiences and are used to contribute to the generation of a hypothesis and construction of a theory about factors influencing F/EL motivation.

The data extracted from the aforementioned sources was analyzed inductively, moving from specific to general and with insufficient knowledge available about the studied phenomenon. The aim behind this was to identify key lexical items structuring the discourses of the informants, NELP and the pertinent literature, and help identify any inter-textual similarities, agreements and harmony. Semantic and syntactic content analyses thus contribute to the author's general thinking and interpretation and the development of a relevant hypothesis. There is a substantial amount of relevant information about the political, social, and cultural forces influencing motivation about E/FL in the Omani language education system.

To improve quality, reliability and validity, the interview questions were piloted on six volunteers from SQU and the Ministry of Education, who represented different backgrounds and held different experiences, notions, values, perceptions, beliefs and thoughts about factors influencing E/FL motivation.

\section{RESULTS AND FINDINGS}

Different themes have emerged from the analysis of the data, which have been inspired by the pertinent literature and NELP. Those are: The environment, media, family, total immersion, work and school.

\section{A. Environment}

Informant \#1 compares between Adam, her hometown, and Muscat and believes that the latter environment furnishes better chances for language exposure and practice.

For example, when I was in Adam (a small remote village in the interior region of Oman) in my secondary school I didn't use it [English] at all. I think those who live here in Muscat use it a lot with others, in dealing with others, for example, at big centers, big supermarkets, or other places like that.

The places used as examples by this informant - "big centers" and "big supermarkets" or as they are known today by "hypermarkets" - are often visited by male and female Omani youth, especially during the summer holiday when schools are closed and the weather is very hot with temperatures exceeding 40 degrees centigrade even during the night sometimes. Such places facilitate socialization and social gatherings through the wide array of shopping facilities and experiences they offer.

There is indirect reference made in this informant's statement to the role intrinsic and extrinsic motivations play in English language practice and use. While the two types of motivation are different, they can exist side by side in an individual.

\section{B. Media}

Informant \#2 claims that she learned English through variable sources. "I learned English through reading some books ... I also learned it from the TV and from the radio". Similarly, informant \#3 believes he learned English through channels external to the school and teacher "I learned English through watching TV, series, movies and reading books".

These informants learned English because they had a variety of sources to acquire the target language from. Such sources can contribute to students' oral and written English language development. In addition, such sources mostly presented the target language through fun and entertainment. These informants were intrinsically motivated to acquired English in a pressure and anxiety-free environment and through the use of accessible tools and ones which they presumably enjoyed using most beyond the school and classroom boundaries and with minimal or no interference from the teacher.

\section{Family}


Informant \#4 looks at motivation from a broader angle. She thinks that the family and the home environment have a major and supportive role to play in driving and fostering motivation about acquiring English language leading to linguistic development.

If a child is learning English, for example, let's say like in Oman, and they're just doing a sort of five classes of English a week ... and they go back to their home environment, they have either family or people working in the home environment, who actually use English as a medium of communication. Then, I think naturally that child is going to have more exposure to the language and is going to pick up the language faster and more easily than a child in the same class, who goes back into an environment where there is no English spoken; there's no exposure to English either through people working in the house, parents talking in English, radio being listened to, films being watched, there are no books around at home. Then, I think it would be naturally more demanding for that child to learn English at the same rate as the other child.

There are a number of effective out-of-classroom target language learning strategies mentioned here.

Informants \#2, \#3 and \#4 highlighted the role of materials and sources that include a high degree of the culture(s) of the target language. Examples have been the media, books and the native speaker.

Reference is being made to the role of the family in providing a stress and control-free environment for accessing the target language and positively impacting the students' motivation. The role of the family in language maintenance is also considered important. English here is seen as one of the languages that can be maintained by the families in Oman, as it is the case with Arabic and the several indigenous languages, for example.

It is further interesting to note that informant \#4 is very familiar with the structure and functions of the Omani society, as she has been in Oman for over 25 years and worked as a teacher of different levels in different areas of the Sultanate until she became an Inspector. However, it is interesting to note that she is using the "radio" and reading "books" as examples of exposure to language. I argued above that such sources of language exposure are not as commonly used as three or four decades ago, especially in Muscat the capital. However, this informant mentioned "exposure to English either through people working in the house". Reference here is being made to servants. Almost all middle-class families in Oman in general and in Muscat in particular recruit female servants from India, Sri Lanka, Indonesia and the Philippines. This expatriate labor force mostly uses English as a medium of communication. English is, therefore, used for inter-lingual communication purposes even by the non-Arab tourists and visitors. It bridges the linguistic gap between the Omanis and the non-Arab guest workers.

Informant \#5 thus states that she acquired her English at home. "I used to speak English at home with my sisters and brothers and with the maids. So the whole environment at home was English". This informant has the power to influence her student teachers' beliefs and attitudes about using English all the time with their students in the classroom. She can do this through transmitting her personal experience to them.

Another natural source of language exposure and practice leading to motivation consolidation and highlighted by the last two informants is the housemaids or the servants. This informant comes from a high class family. Such families in Oman and the neighboring Gulf countries usually hire more than one servant from the aforementioned countries at the same time and opt for those with a certain level of education and experience to ensure provision of the best care for their children.

\section{Total Immersion}

Informant \#6 looks at the environment from the total immersion perspective. She lived in Hungary for three years and learned Hungarian as she was immersed in the culture and the language. "I learned Hungarian in three year. I lived in Hungary so I was immersed in the culture and the language. I spent a lot of time with Hungarians, who could not speak a lot of English". This informant is an outgoing, self-confident, and motivated person with positive attitudes, who adopted an out-of-classroom strategy through mixing with the natives of the language and sought interaction and practice opportunities to reach her appropriate goal of mastering a foreign language.

On the contrary, informant \#7 describes her experience in learning French in USA, which included the element of anxiety. However, she thinks that she leaned French better when she lived there for some time and mixed with the natives of the country.

When I learned French I wasn't that fluent. When I went to France and lived there my French improved really a lot. But when I was in the United States I was afraid I would make mistakes if I talked French or people would laugh at me.

This informant suffered from a psychological strain represented in anxiety and poor confidence, which has impacted her motivation. She was afraid of being evaluated negatively by the people.

\section{E. Work}

Informant \#8 believes that a foreign language is learnt better and faster for reasons associated with instrumental motivation. He thinks that "there are a few factors here. There's motivation ... for jobs ... for a career ... for more money". All the reasons provided here are goal-governed and economically-driven. The same informant (\#8) believes that working with French made him acquire a native-speaker like ability. He learned the language formally and acquired it through social contact. These two channels of exposure to the target language helped him develop a native-speaker like competence. He perceives his situation as very closely resembling the Omani students' situation about learning English for job purposes. 
I also had some French and my French now is much better. I was more or less like a native speaker at one stage, because I was working in the language. I was working in French, attending meetings in French. That was the key thing - having to use the language.

Informant \#9 also advocates the concept of instrumental motivation using his own experience. "Now, if you look at people, for example, the drivers or the cleaners and the salesmen. These people learn Arabic fast because it is a necessity for their job". These laborers in Oman mainly come from India, Pakistan, and Bangladesh. While few Omanis speak Hindi or Urdu, none speaks Bengali. Acquisition of and communication in Arabic for the Indians, Pakistanis and Bengalis is hence driven entirely by instrumental motivation.

Thus, informant \#10 looks at the Omani students as lacking instrumental motivation and that it is affecting the Sultanate's economic growth. English is necessary for national development and for bringing about positive social change.

Students don't understand why this language is taught in the country, in spite of the fact that Oman's revenue come possibly from $90 \%-95 \%$... from those who use English in their work places, and English is very important in all industries, business and a number of other professions in Oman. It is really important for those students to know why it is taught in the country and its importance in the labor market, which is the future of this country. Unfortunately many kids are not aware of it at all.

This informant is in a position to influence positive policy implementation through educating the students he meets with when he accompanies his student teachers to their practicum. He can also advise his student teachers to play the same role as his with their students at school. As a teacher trainer, he is a powerful socialization agent and an individual, who possesses substantial sanctioning power over his student teachers.

This informant, who has received his school education in Zanzibar where English enjoys an official status, examined and investigated in his Doctorate thesis the place of English in the private sector and what future lies ahead for English. His mention of the industrial and economic role of English is directly influenced by the study he has conducted in 1995.

The mention of "industries" and "business" here indicates the importance of English for business and technology and working in these two fields. This appears evident from his reference to the "labor market". Oman needs acquisition of technology since it is fundamental for business and industry development. Oman is not an industrial country, but it has trade links with the world, which largely uses English for trade and business transactions. In the age of globalization and where the world is shrinking and becoming one small village, Oman cannot live in isolation from the rest of the world.

Informant \#11 believes that students in Oman do not see the relevance of English for socioeconomic purposes.

They [the students] should be aware of the current situation. They don't know really why they are learning English. They should be enlightened with the current situation because you know the English language is very important nowadays for someone to get a job in our country. These things should be discussed with the students.

This informant, who has highly positive attitudes towards learning English has been learning it for the past 13 years and his social contacts with the various students have made him believe that many of them still cannot see the relevance of English. Being a future English teacher and someone who has decided to work in ELT, he believes that English is very important for getting a job. This informant has instrumental motivation and is aware of the important role of English to the extent that he has been to an English speaking country already to improve his English proficiency.

\section{F. School}

Those who see the relevance of English are the ones who see it through the lenses of passing exams with high marks. Exams as an indication of success in second language learning present a big problem to the Omani students. Informant \#12 thinks that "students do not learn English for the sake of learning a language. Rather, it is just to pass the examinations".

Informant \#4 states that "teachers train for the exams" and that "the whole nature of the exam system is an absolute fuss and it reflects badly when they are [the students] at Grade 12". This is the case in Oman where some teachers give private tutorials/lessons to Grade 12 students whose parents can afford the fees and are willing to invest in tutoring in order to prepare their children specifically for the exam. The fees can reach as high as U.S. \$30-40 per student per hour. This even occurs sometimes during school hours and applies to subjects like Arabic Language, Maths, Chemistry, Physics and Biology. Teachers giving these kinds of lessons, and those teaching at public schools too, usually use past exam papers to train the students to answer the end-of-semester exam questions.

Informant \#13 critically describes the way he was taught English and the level he had reached.

We are learning English strictly for exam purposes. I can translate in writing, but I wouldn't be able to talk, despite the fact I have good vocabulary. This is what we miss today, the modern way of teaching English. There has to be a kind of solution to this problem. It cannot be solved through our curriculum. This is of course the concern and the responsibility of the educational system, not ours.

Higher education institutions in Oman, almost like anywhere else in the world, accept those with the highest scores in Grade 12 exams. Exam score is critical for a student's career path and future earnings. Public higher education institutions implement this policy more religiously than the private institutions due to the limited available seats at the different undergraduate academic institutions. 
Thus, informant \#14 thinks that "students should be motivated by their parents, by the society, by the headmaster, and by the academicians". She further thinks that "schools should hold a school council and invite parents to attend and discuss the problems related to their children". The role of the society, hence, in accepting and understanding the values of English is important in facilitating successful language education implementation. Societies influence language spread and maintenance perhaps as much as governments do. Involving parents in such forums can positively impact the English language policy implementation. Language change is primarily concerned with bringing about positive change to the society.

There are, however, some Omani parents, who do not work in English. There are also many parents who cannot read and write, or can read but not write. There are additionally many parents, who cannot even speak Arabic fluently. There are also many parents, who live in areas in Oman, where exposure to English is extremely limited or hardly exists. Moreover, there are many parents, who are a product of Quranic schools, or who have never been to school themselves. Furthermore, there are parents, who prefer to see their children find a job immediately after completing Grade 12 for economic reasons. Parents with this level of literacy, education, circumstances, attitudes and perceptions surely cannot contribute to their children's awareness or motivation.

It is noteworthy that some schools in Oman hold councils and invite parents to meet with teachers. However, discussions mostly revolve round students' achievement and the marks they have scored in their tests. Another aim for such councils is to raise funds to help construct various projects related to the school premises. Such meetings are usually held once every semester or once a year.

Informant \#11 states that "at school we learned English compulsory, not for interest. We studied grammar rules. We had to read books at school, activity and pupil books".

This informant has instrumental and intrinsic motivation and has opted for becoming an English teacher. He is apparently enjoying what he is doing and learning at present. As an ELT student teacher, who has been exposed to different educational, social and psychological theories of teaching and learning, he has developed a firm belief about the key role of motivation for activating learning, especially in EFL contexts, where the uses and values of learning English are not visible. His critical statement is based upon his reflection on his personal knowledge and experience as a school student and college student, which have shaped his ideologies.

Informant \#10 believes that English is one of the least popular subjects because the students fail to see its communicative and functional value and fail to use it interactively.

Most students are just surviving from day to day wanting the hours to go as quickly as possible. Most of them have lots of problems with their English. While language is for communication they fail to communicate even simple sentences. As a result, due to lack of success these students lose interest, lack motivation and as a result it is not one of the loved subjects in many schools in Oman.

This informant is describing Omani students of English as "demotivated" and "amotivated", who have lost their interest in learning the language and have no goals and motivation to make any move due to lack of self-esteem and interactive use and practice of the target language.

Informant \#15 thus believes that students fail to see the significance of English for communicative purposes due to the fact that it is just another fact-based-like school subject, which they need to pass and forget about after leaving school. "Students have to memorize it, pass the test and forget it ... English is not seen as means of communication, but like any other fact-based subject. Some students see it as a mountain or a hurdle that should be really overcome".

The last two informants have been teaching at SQU for over 20 years. They taught English at different schools and institutes prior to obtaining their Ph.D. They have been involved in different activities and technical committees about ELT at SQU and beyond, which have exposed them to sufficient ELT theory and practice. They are aware that students at SQU are indifferent from those at school in terms of possessing extrinsic motivation that strongly influence their way of perceiving English. Many faculties at SQU concentrate on short tests (quizzes) and give them a distinct edge over continuous assessment. Such tests gauge students' memory rather than their cognitive skills, which is typical of education in the Arab World and which contradict the aims of progressive and humanistic education. Such a situation further negatively impacts the preparation of national manpower for the local and global job markets in an ever evolving, demanding and challenging economic world almost entirely driven by globalization and internationalization.

\section{IDEOLOGICAL DimENSION IN OWTE}

Language in OWTE is described as communication, "that is giving and receiving information" (Teacher's Guide, Elementary Level, p. 2) and that "speaking is the most common form of communication" (Teacher's Guide, Preparatory Level, p. 37). Both books claim that language is used mainly for three functions: "descriptions, narratives and instructions" (Teacher's Guide, Elementary Level, p. 3). There is no place here for literary language.

Knowledge goes from the teacher to the children ... the teacher exposes the children to the new language ... sometimes actions or realia are used to help understanding ... later in the lesson when the teacher is sure that most of the children understand what they have heard, they are given the chance to produce language about the topic ... it is important that you use as much English as possible ... if you do, you may find your children learn more from you than from their books (Teacher's Guide, Elementary Level, p. 2). 
Teachers are invited to go beyond the Teacher's Guide and bring some of their own experience and knowledge to the classroom, even though this is more confined to the experienced teachers. "If you are a new teacher follow the procedure in the Teacher's Guide very closely. Do the same if you are using a new book. If you do this, you will achieve the aims of the lesson" (Teacher's Guide, Elementary Level, p. 31). Even the experienced teachers are allowed to supplement the textbook and go beyond the Teacher's Guide under certain conditions represented in completing the syllabus. "It is important ... that you complete the syllabus as this is what you test" (Teacher's Guide, Elementary Level, p. 33).

Sometimes the Teacher's Book makes suggestions for extra activities. You must decide how you spend this time ... with a difficult lesson and a weak class you will need to find some extra time perhaps by omitting some easy steps or even by using extra lessons ... once you have used a Teacher's Book from start to finish, you are free to adapt it or even use different texts or tasks as long as you achieve the same aims ... you must plan any changes very carefully. Your inspector, for good reasons, may insist that you follow the Teacher's Book exactly (Teacher's Guide, Elementary Level, p. 33-34).

Teachers are not in a position to make decisions inside the Omani classrooms and resort to their creative and innovative skills. Adapting to such a rigidly controlled situation is considered a priority and has an edge over the learning process and quality of delivery, which makes teachers appear as lacking teaching skills and advocates conventional teaching methods, and hence, demotivates the learners.

The Teacher's Guide, Elementary Level (1997-98) states that learners learn when they are enjoying themselves and finding things out for themselves, or via discovery learning. In other words, there is emphasis laid on autonomous learning where students actively and dynamically take initiatives and direct and regulate their learning, make decisions about their learning, think independently, manipulate knowledge and create meaning with minimum reference to the teacher. This is bound to prepare students to become life-long and autonomous learners, who possess higher motivation leading to producing better and more effective work.

However, the Teacher's Guide, Preparatory Level (1997-98) encourages teachers to collect texts and articles related to the topics of the textbook and present them in a simplified language. The incredible and rapid growth of knowledge at present, particularly via the Internet and the press, necessitates its introduction to the students. Such control over knowledge can reflect badly on the teacher's image in terms of his/her depth and breadth of knowledge, and hence, demotivates the students.

OWTE thus contains simplified listening tasks, a few songs and rhymes on the accompanying tape, which attempt to stress certain lexical and structural aspects of the lesson or topic introduced. The tasks, which contain a native speaker, are primarily for the students to listen to and try and model their pronunciation. In other words, OWTE restricts access to the native speaker. The students listen to the mandated textbook's language and voice more through the carefully controlled presentation of the teacher. There is more or less a cycle through which the activities are used repetitively, which has been a demotivating factor for English learners.

Teachers are given freedom but within a predefined and strict limits and parameters. Cultural appropriateness still serves colonizing the students' minds and values so as to produce domesticated natives, who think within limits and acquire predefined knowledge, but do not critique or examine, which is bound to contribute to the students' demotivation and amotivation.

\section{DISCUSSION}

Motivation, as found in the literature and NELP, is a significant factor in the development of the target language. Several internal and external factors have been found powerfully influencing motivation to acquire and learn a language of wider communication like English, for example, and hence, impact positive policy implementation. Gholami, Abd Rahman and Mustapha (2012) thus support schools taking students on expedition tours and arranging workshops for them to help increase their motivation through providing them with genuine opportunities to listen to and speak the target language. Tuan (2011) considers the students' awareness about the role of the second language for future career as a motivating factor. Benson (1991) suggests that students' rejection of instrumental motivation is an indication of the way they perceive English as not playing any vital role in their lives. Within the same vein, Ngeow (1998) argues that if students do not perceive English as relevant and transferable to other situations, learning to them will become meaningless and their motivation to acquire the target language will decrease. Students, therefore, and according to Warrington and Jeffrey (2005) need to see English as an international language, which is used widely by native and non-native speakers and one which stretches beyond national boundaries to help its users achieve multiple significant aims. Kachru (1986) suggests that English has "material parameter" where it is considered as a "tool for mobility, economic gains and social status" (p. 130). English, hence, is “... functionally attractive" and provides "... access to higher education" (de Klerk 1999, p. 316).

Moreover, Gholami et al. (2012) highlight the significance of the TV, radio and newspapers as rich sources that provide comprehensible input and variable exposure to the target language and the native speaker. This, according to Gholami et al., is bound to motivate the learners about learning English. The concept and definition of TV has changed today. The vast number of free-to-air and paid channels broadcasted in English has redefined the role of TV. There is a much bigger variety of channels in English to choose from than it was the case around two decades ago. There is almost 
everything for every taste, age and background, which can drive people's intrinsic motivation to acquire authentic language while at the same time enjoying themselves. The same applies to the printed word in English, which has become available electronically and has become more accessible than ever. Various newspapers and magazines are available online for Internet users to browse, and hence, develop their linguistic and repertoire. Several authors have stressed the interlocking relationship between language and culture and how the two strongly complement one another (Jiang, 2000; Peterson \& Coltrane, 2003). Scarcella and Oxford (1992), therefore, state that "motivation often leads learners to use a variety of learning strategies that can develop greater skill in language learning" (p. 191). Schools, therefore, can be considered as powerful socialization and enculturation agencies that can have their own agendas through which they shape students' ideologies for better or worse.

Tuan (2011) found that lack of self-confidence is a demotivating factor in learning English. Teachers, according to Zhao (2012), are thus responsible for helping students to overcome such feelings and develop their self-confidence through helping them to build up positive perceptions about themselves and create motivational conditions in the classroom. Al-Bulushi and Al-Issa (2012) highlight the pivotal role of teachers in English as a foreign language contexts, like the Omani one, in encouraging, guiding, directing, advising and helping their students to improve their productive or active language capacity through adopting strategies that engage them in using the productive skills of the target language, which can have positive implications for their self-confidence and motivation.

However, Al-Toubi (1998) and Al-Issa (2010) argue that the curriculum is rigidly controlled and does not provide sufficient room for spoken language and integration of the four skills, gives usage and product an edge over use and process, and lacks both authentic materials and communicative language practice activities. Al-Alawi (1994) and AlHammami (1999) are thus critical of the education system in Oman and describe it as authoritative, rigid, and highly centralized. Both authors found that the Ministry of Education governs and controls the teaching methods used by the teachers. Al-Alawi (1994) further found that restrictions imposed upon the teachers to use the Teacher's Guide have had an influence on the teaching methods they have employed. Moreover, Al-Toubi (1998) found that the curriculum is implemented in a top-down mode. Al-Toubi argues that this has made it very difficult for teachers to engage in any kind of change or innovation.

Al-Toubi (1998) further found that the exam-based system is one of the reasons behind the students' poor level in English in Omani. He concludes that this has negative implications for the students' language development. Al-Issa (2010) argues that exams in Oman encourage and demand production of information in masses, while ignore proficiency. According to Shor and Freire (1987), education conducted in this manner is much more controllable and facilitates quantitative measurement learning. They view this as coming at the expense of developing the right thinking skills. Performance-based tests as opposed to criterion-referenced tests and mastery of content and achievement grades have always powerfully affected the students' and teachers' performance and motivation in the Omani ELT system (AlIssa, 2010). Dove (1986) acknowledges that the pressures applied on the teachers by examinations restrict the teachers' conceptions of their responsibilities as professionals. Dove (1986) acknowledges that examinations are a major influence on how teachers interpret the curriculum. Gardner (1985) comments that having to learn English because it is another school subject on the curriculum cannot be considered as any kind of motivation and that it is this situation that best describes why students at school fail to perform well in English and meet the expected standards. Norris-Holt (2001) establishes a link between communicating successfully using the target language and the feeling of sense of accomplishment student develops accordingly. Li and Pan (2009) additionally state that “... students who have no success in the process of learning English may give up their learning behaviors which may lead to their failure in exams" (p. 127). Research has shown that there is significantly positive correlation between motivation in learning English and proficiency on the one hand and achievement on the other hand (Choosri \& Intharaska, 2011). Teachers, thus, have a significant role to play here through recognizing their learners' effort, no matter how little and limited and celebrate their success, as lack of this can demotivate students (Tuan, 2011). Oxford and Ehrman (1993) state that research shows that “... students who are more motivated develop stronger overall L2 proficiency” (p. 191).

Accordingly, Al-Issa (2010) criticizes the teaching methodology in Omani schools for being very formal and emphasizing a largely passive role for students with an emphasis on rote learning. Ma and Ma (2012) stress that students feel highly motivated "... when their wants and needs are taken into account and when they have their voices heard by others" (p. 841). On the contrary, "compulsory" English learning, according to Tuan (2011), is a demotivating factor in ELT. Oxford and Ehrman (1993) claim that "motivation encourages greater overall effort on the part of the language learners and typically results in greater success in terms of language proficiency and achievement" (p. 191). Research has shown that there is a positive relationship between higher proficiency level and positive attitudes and motivation to learn English (Ming, Ling \& Jaafar, 2011). Martin and Midgley (1991) suggest that "mastery learning" enhances students' motivation to learn. Mastery learning is a type of learning based on practice through which students develop the ability to apply knowledge in the real world. The two authors consider the educational policies responsible for emphasizing this. Oxford and Ehrman (1993) claim that "if language activities are perceived as irrelevant or uninteresting ... the learner might tune out or lower the level of involvement" (p. 191).

It is thus interesting to note that the Teacher's Guide, Preparatory Level (1997-98) confines the collection of texts and articles to the topics in the textbook. Topics still have the upper hand in the classroom. Emphasis is still laid on the 
"selective traditions" (Williams, 1989) and "interested knowledge" (Pennycook, 1989), which guarantee the transmission of certain values, beliefs and traditions through the target language.

Textbooks within the Omani ELT context, as it is the case with many other contexts worldwide, typically guarantee transmission of selective traditions and interested knowledge and that all students receive common and fundamental knowledge through exposure to certain authorized and prescribed texts (Luke, de Castell \& Luke, 1989), which focus largely on the local culture, and hence, hinders the nurturing of integrative motivation. Language, hence, becomes subservient to knowledge and culture. Textbooks, in a context like Oman's, as it is the case in many other contexts round the world, are sacred, have supremacy over the teacher and students and are targeted to the entire student population, which makes them an economic commodity. Apple (1993) claims that standardized textbooks have an ideological dimension as they help teachers overcome problems related to large classrooms, as it is the case in Oman, where classrooms comprise of a minimum of 35 mixed-ability students and are not conducive for language learning. Tuan (2011) considers classroom atmosphere or environment as one of the significant English language learning demotivating factors.

Moreover, textbook production is an economic aspect of education. Textbooks are produced in masses and are targeted to all students without any exceptions and regardless of their backgrounds, age, needs, interests, wants, motivation, skills and abilities. Textbooks are devices for putting ideas and beliefs above criticism (Olsen, 1989) and are tools for transmitting cultural, political and economic ideologies of the elite (Havelock, 1989). Freire (1970) describes this as the "banking" concept whereby teachers "deposit" knowledge taken from the dominant culture in the minds of their students, which is particularly the case in Oman. Textbooks, therefore, should not be seen as the only source of language and as a central part of the ELT process that activate motivation, particularly that "... the OWTE materials have been written so that the average child will be aware of his progress as he uses them" (Teacher's Guide, Elementary Level, p. 2).

The quality of general and higher education in general in the Arab World in general and the Gulf countries in particular, which Oman is a part of, has been thus criticized by the World Bank development report released in 2008 on the Middle East and North Africa (MENA) countries and by Al-Dhafiry (2003) and Al-Suwaidi (2010) respectively for being "low", "background" and one which has failed so far to bridge the gap between the economic needs and educational objectives. This has subsequently caused it to fall behind other regions in the world and lead to an unemployment crisis (Maroun, Samman, Moujaes \& Abouchakra, 2008). It has further given foreign skilled labor particularly from Indian, Pakistani and Bangladeshi an edge over their Gulf counterparts in terms of filling the available jobs (Al-Suwaidi, 2010).

The World Bank development report criticizes education in the MENA countries for focusing more on encouraging memorization and transmission of facts, repetition of definitions, passive reception of knowledge, acquisition of declarative knowledge at the expense of procedural knowledge, textbook dependency, didactic, adoption of teachercenteredness. On the contrary, it has paid limited attention to significant issues pertinent to progressive education like individual differences in the classroom, interactive learning, student-centeredness, and introduction and development of higher-order cognitive skills. This is bound to negatively impact high productivity and rapid economic growth.

Akkari (2004) thus argues that students in the MENA countries need to be taught technical skills like problem solving, critical thinking, innovation, creativity and cooperation in order to “... function effectively in tomorrow's world" (p. 151) and gradually reduce the high unemployment rates amongst Grade 12 graduates (Gonzalez, Karoly, Constant, Salem \& Goldman, 2008). Furthermore, unemployment rates are high amongst Grade 12 graduates. Gonzalez et al., (2008) attribute this to "lack of skills and competencies necessary for productive work" (p. 165). One of these necessary skills and competencies is obviously the English language.

\section{CONCLUSION}

This study critically investigated factors underlying E/FL motivation with a particular reference to the Omani ELT context. The paper triangulated data from different semi-structured interviews made with different informants involved in the Omani ELT system, NELP, OWTE and the pertinent literature.

The findings have revealed that ELT theory and practice within the Omani ELT education system are moving in two parallel lines. This can negatively influence preparing competent Omani English language users, who can contribute to effective implementation of Omanization.

Having said that, proficiency in English language, as it is the case with any foreign language is complex and motivation lies at the heart of it. The discussion has revealed that there is an urgent and pressing need for bridging the ideological gap between ELT theory and practice in Oman on the one hand and between those involved in constructing the ELT policies and those who implement them on the other. The findings and discussion have revealed that the informants have variable degrees of knowledge, experience and power stemming from their different social interactions and positions, which can have variable degrees of influence on policy implementation, but which can be directly and indirectly oppressed and suppressed in a rigidly controlled and centralized context, which slams the door in the face of change, creativity and innovation.

The ELT filed has evolved at an incredible pace over the past few decades and witnessed the rise and fall of various teaching and learning theories, which lays additional responsibilities over the policy makers' shoulders to keep abreast 
with these changes and challenges to help produce linguistically adequate Omanis with a capacity to fulfill the needs and meet the expectations and demands of the ever economically-driven world.

\section{APPENDIX}

TABLE 1:

BACKGROUND INFORMATION ABOUT RESEARCH PARTICIPANTS

\begin{tabular}{|c|c|c|c|c|c|c|c|}
\hline No. & Status & Gender & Age & Nationality & Qualification & $\begin{array}{l}\text { Years in } \\
\text { Oman }\end{array}$ & Responsibilities \\
\hline 1 & Grade 12 Student & $\mathrm{F}$ & 17 & Omani & Grade 11 & & Student \\
\hline 2 & $\begin{array}{l}\text { Public } \\
\text { School Head }\end{array}$ & $\mathrm{F}$ & 51 & Omani & Diploma & & $\begin{array}{l}\text { Responsible for running public schools and } \\
\text { implementing school and ministerial policies }\end{array}$ \\
\hline 3 & $\begin{array}{l}\text { Public Education } \\
\text { Teacher }\end{array}$ & M & 54 & Jordanian & B.A. & 19 & Teach English to and assess public school students \\
\hline 4 & $\begin{array}{l}\text { Private } \\
\text { Education } \\
\text { Inspector }\end{array}$ & $\mathrm{F}$ & 59 & Irish & M.A. & 26 & $\begin{array}{l}\text { Inspect quality of ELT instruction in private schools } \\
\text { and design and run in-service courses for ELT teachers } \\
\text { in private schools }\end{array}$ \\
\hline 5 & $\begin{array}{l}\text { SQU College of } \\
\text { Education } \\
\text { Lecturer }\end{array}$ & $\mathrm{F}$ & 29 & Omani & M.A. & & $\begin{array}{l}\text { Teach ELT methodology and teaching practice to third } \\
\text { and fourth year ELT specialists and supervise } \\
\text { practicum }\end{array}$ \\
\hline 6 & $\begin{array}{l}\text { Private } \\
\text { Education } \\
\text { Teacher }\end{array}$ & $\mathrm{F}$ & 32 & Irish & Diploma & 17 & Teach English to and assess private school students \\
\hline 7 & $\begin{array}{l}\text { ELCD Assistant } \\
\text { Director }\end{array}$ & $\mathrm{F}$ & 51 & Omani & M.A. & & Execution of administrative tasks \\
\hline 8 & $\begin{array}{l}\text { ELCD Chief } \\
\text { Inspector }\end{array}$ & $\mathrm{M}$ & 51 & English & M.A. & 26 & Responsible for ELT inspectors throughout Oman \\
\hline 9 & $\begin{array}{l}\text { Public Education } \\
\text { Inspector }\end{array}$ & $\mathrm{M}$ & 52 & Indian & M.A. & 21 & $\begin{array}{l}\text { Inspect quality of ELT instruction in public schools and } \\
\text { participate in running in-service courses for ELT } \\
\text { teachers }\end{array}$ \\
\hline 10 & $\begin{array}{l}\text { SQU College of } \\
\text { Arts Assistant } \\
\text { Professor }\end{array}$ & $\mathrm{M}$ & 62 & Omani & Ph.D. & & $\begin{array}{l}\text { Teach English language and English literature to } \\
\text { second, third and fourth year ELT specialists and } \\
\text { supervise practicum }\end{array}$ \\
\hline 11 & $\begin{array}{l}\text { SQU Student } \\
\text { Teacher }\end{array}$ & M & 21 & Omani & $\begin{array}{l}\text { SQU } \\
\text { Final Year }\end{array}$ & & $\begin{array}{l}\text { Student } \\
\text { Teacher }\end{array}$ \\
\hline 12 & $\begin{array}{l}\text { ELCD } \\
\text { Curriculum } \\
\text { Officer }\end{array}$ & $\mathrm{F}$ & 61 & Omani & M.A. & & Responsible for Curriculum and syllabus design \\
\hline 13 & $\begin{array}{l}\text { Public School } \\
\text { Head }\end{array}$ & $\mathrm{M}$ & 56 & Egyptian & B.A. & 16 & $\begin{array}{l}\text { Responsible for running public schools and } \\
\text { implementing school and ministerial policies }\end{array}$ \\
\hline 14 & $\begin{array}{l}\text { Private } \\
\text { Education } \\
\text { Inspector }\end{array}$ & $\mathrm{M}$ & 37 & Indian & M.Ed. & 14 & $\begin{array}{l}\text { Inspect quality of ELT instruction in private schools } \\
\text { and design and run in-service courses for ELT teachers } \\
\text { in private schools }\end{array}$ \\
\hline 15 & $\begin{array}{l}\text { SQU College of } \\
\text { Arts Associate } \\
\text { Professor }\end{array}$ & M & 57 & Sudanese & Ph.D. & 24 & $\begin{array}{l}\text { Teach English language and English literature to } \\
\text { second, third and fourth year ELT specialists and } \\
\text { supervise practicum }\end{array}$ \\
\hline
\end{tabular}

\section{REFERENCES}

[1] Akkari, A. (2004). Education in the Middle East and North Africa: The current situation and future challenges. International Education Journal 5, (2), 144-153.

[2] Al-Alawi, K. (1994). The teaching and learning of English as a foreign language in 3rd yea rsecondary education in Oman with special reference to reading. Unpublished doctoral dissertation, University of Bath, England.

[3] Al-Bulushi, A. \& Al-Issa, A. (2012). Investigating Omani learners' out-of-class English language learning strategies. In A. Mahmoud \& R. Al-Mahrooqi, Issues in teaching and learning English as a foreign language in the Arab world (pp. 271-294). Muscat: Sultan Qaboos University Academic Publication Board.

[4] Al-Busaidi, K. (1995). English in the labour market in multilingual Oman with special reference to Omani employees. Unpublished doctoral dissertation, University of Exeter, England.

[5] Al-Dhafiry, A. (2003). Unemployment in the Gulf countries: Reasons and remedies. Applied Econometrics and International Development 3 (3), 61-82.

[6] Al-Hammami, H. (1999). Education for the 21st century general education reform in the Sultanat eof Oman: motives, nature and strategies of implementation. Unpublished doctoral dissertation, University of Birmingham, England.

[7] Al-Humaida, I. (2012). Research on motivation to learn English among college students in Sudan. English Language Teaching, 5 (8), 49-56. Available athttp://www.ccsenet.org/journal/index.php/elt/article/view/18614 (accessed 2/4/2013).

[8] Al-Issa, A. (2010). Factors influencing critical thinking in the ELT context. In R. Al Mahrooqi \& V.Tuzlukova (Eds.), The Omani ELT symphony: Maintaining linguistic and socio-culturalequilibrium (pp. 169-202). Sultan Qaboos University, Oman.

[9] Al-Mahrooqi, R., Abrar-Ul-Hassan, S. \& Cofie, C. (2012). Analyzing the use of motivational strategiesby EFL teachers in Oman. Malaysian Journal of ELT Research, $8 \quad$ (1), 36-76. Available athttp://www.melta.org.my/majer/AlMarooqi\%20et\%20al.pdf (accessed 2/4/2013). 
[10] Al-Mamari, A. (2007). The effect of teaching EFL online on the achievement and attitudes ofgrade 11 students. Unpublished masters dissertation, Sultan Qaboos University, Oman.

[11] Al-Suwaidi, J. (2010, February 3). Concluding remarks: Adapting education to labor market needs. Paper presented at The Emirates Centre for Strategic Studies and Research conference, Abu Dhabi, United Arab Emirates.

[12] Al-Toubi, S. (1998). A perspective on change in the Omani ELT curriculum: structural to communicative. Unpublished master dissertation. University of Bristol, England.

[13] Apple, M. (1993). Official knowledge. New York: Routledge.

[14] Baldauf, R., Jr. (1990). Language planning and education. In R. Baldauf, Jr. \& A. Luke (Eds.), Language planning and education in Australia and the South Pacific (pp. 14-24). Clevedon: Multilingual Matters.

[15] Benson, M. (1991). Attitudes and motivation towards English: A survey of Japanese freshmen. RELC Journal, 22 (1), 34-48. Prentice Hall Regents.

[16] Brown, H. (2007). Principles of Language Learning and Teaching. 5th ed. San Francisco StateUniversity.

[17] Choosri, C \& Intharaksa, U. (2011). Relationship between motivation and students' Englishlearning achievement: A study of the second-year vocational certificate level Hatyai Technical College students. A paper presented at the $3^{\text {rd }}$ International Conference on Humanities and Social Sciences, Songkla University, Malaysia.

[18] Costa, B. (2011). The English language experience: The importance of the students' motivation in English as a foreign or second language classes. Revista $\quad$ Litteris, $8, \quad 201-213$ Available at.http://revistaliter.dominiotemporario.com/doc/ARTIGO_BRUNO_CORIOLNO_2011_LITTE.pdf (accessed 2/4/2013).

[19] Dahmardeh, M. \& Hunt, M. (2012). Motivation and English Language Teaching in Iran. Studies in Literature \& Language, 5 (2), 36-43. Available at http://www.cscanada.net/index.php/sll/article/view/j.sll.1923156320120502.78/3435 (accessed 2/4/2013).

[20] Davies, P., \& Pearse, E. (2000). Success in English teaching. Oxford: Oxford University Press. de Klerk, V. (1999). Black South African English: Where to from here? World Englishes, 18 (3), 311-324.

[21] Dove, L. (1986). Teachers and teacher education in developing countries. London: Croom Helm.

[22] Ellis, R. (1997). Second language acquisition. Oxford: Oxford University Press.

[23] Freire, P. (1970). Pedagogy of the Oppressed. New York: The Seabury Press.

[24] Gardner, R. (1985). Social Psychology and second language learning: The role of attitudes andmotivation. London: Edward Arnold.

[25] Gardner, R. \& Lambert, W. (1972). Attitudes and motivation in second language learning. Rowley,Mass: Newbury House.

[26] Gee, J. P. (1990). Social linguistics and literacies. London: Falmer Press.

[27] Gholami, R., Abd Rahman, S. \& Mustapha, G. (2012). Social context as an indirect trigger in EFL contexts: Issues and

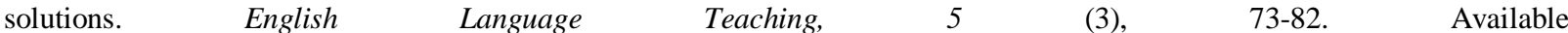
ahttp://www.ccsenet.org/journal/index.php/elt/article/view/15268 (accessed 2/4/2013).

[28] Gonzalez, G., Karoly, L., Constant, L., Salem, H. \& Goldman C. (2008). Facing human challenges of the $21^{\text {st }}$ century. Qatar Policy Institute: RAND.

[29] Gramsci, A. (1971). Selections from the prison notebooks. New York: International Publishers.

[30] Havelock, E. (1989). Instruction of preliterate cultures. In S. de Castell, A. Luke, \& C. Luke (Eds.), Language, authority and criticism (pp. 223-232). London: Falmer Press.

[31] Jiang, W. (2000). The relationship between culture and language. ELT Journal 45 (4), 328-332.

[32] Kachru, B. (1986). The power and politics of English. World Englishes, 5 (2/3), 121140.

[33] Kong, Y. (2009). A brief discussion on motivation and ways to motivate students in English languagelearning. International Education studies, 2 (2), 145-149. Available athttp://www.ccsenet.org/journal/index.php/ies/article/view/1711 (accessed 2/4/2013).

[34] Li, P. \& Pan, G. (2009). The relationship between motivation and achievement - A survey of the studyof motivation of English majors in Quingda Agricultural University. English Language Teaching, 2 (1), 123-128. Available athttp://sv.libarts.psu.ac.th/conference5/proceedings/Proceedings3/article/2pdf/06.pdf.

[35] Luke, C. de Castell, S. and Luke, A. (1989). Beyond Criticism: The authority of the school textbook. In S. de Castell, A. Luke and C. Luke, editors, Language, authority and criticism (pp. 245-260), London: Falmer Press.

[36] Ma, Z. \& Ma, R. (2012). Motivating Chinese students by fostering learner autonomy in language learning. Theory and Practice in Language Studies, 2 (4), 838-842.

[37] Martin, M. \& Midgley, C. (1991). Enhancing student motivation: A school wide approach. Educational Psychologist, 26 (3\&4), 399-427.

[38] Ming, T., Ling, T. \& Jaafar, N. (2011). Attitudes and motivation of Malaysian secondary students towards learning English as a second language: A case study. 3L: The Southeast Asian Journal of English Language Studies, 17 (1), 40-54. Available athttp://pkukmweb.ukm.my/ppbl/3L/3L\%20vol\%2017\%20(1)\%202011/Vol\%017(1)Abstracts.pdf/4.\%20Thang.pdf (accessed 2/4/2013).

[39] Maroun, N., Samman, H., Moujaes, C. \& Abouchakra, R. (2008). How to succeed at education reform: The case for Saudi Arabia and the broader GCC region. Booz and Company. Washington DC. Available at http://www.booz.com/me/home/what_we_think/40007409/40007869/406507 7?pg=all (accessed 19/6/2009).

[40] Ngeow, K. (1998). Motivation and transfer in language learning. ERIC Clearinghouse on Reading, English, and Communication, Bloomington. Available at http://www.kidsource.com/education/motivation.lang.learn.html.

[41] Norris-Holt, J. (2001). Motivation as a contributing factor in second language acquisition. TheInternet TESL Journal 12, (6). Available at http://iteslj.org/Articles/Norris Motivation.html (accessed 2/4/2013).

[42] Nunan, D., Tyacke, M. \& Walton, D. (1987). Philosophy and guidelines for the Omani English language school curriculum. Muscat, Sultanate of Oman: Ministry of Education and Youth.

[43] Olsen, D. (1989). On the language and authority of textbooks. In S. de Castell, A. Luke and C. Luke (Eds.) Language, authority \& criticism (pp. 233-244). London: The Falmer Press. 
[44] Our world through English, teacher's guide, elementary level (1997-1998) (1 ${ }^{\text {st }}$ edition). Sultanate ofOman: English Language Teaching Department, Ministry of Education.

[45] Our world through English, teacher's guide, preparatory level (1997-1998) (1 ${ }^{\text {st }}$ edition). Sultanate ofOman: English Language Teaching Department, Ministry of Education.

[46] Oxford, R. \& Ehrman, M. (1993). Second language research on individual differences. AnnualReview of Applied Linguistics, $13,188-205$.

[47] Pennycook, A. (1989). The concept of method, interested knowledge, and the politics of language teaching. TESOL Quarterly, 23 (4), 589-615.

[48] Peterson, E. and Coltrane, B. (December 2003). Culture in second language teaching. Available at http://www.cal.org/resources/digest/peyton02.html (accessed 20/8/2004).

[49] Petrides, J. (2006). Attitudes and motivation and their impact of the performance of young English as a foreign language. Journal of Language \& Learning, 5 (1), 1-20. Available athttp://www.jllonline.co.uk/journal/jllearn/4_1/petrides.htm (accessed 20/8/2008).

[50] Scarcella, R. \& Oxford, R. (1992). The tapestry of language learning: The individual in the communicative classroom. Boston, Massachusetts: Heinle \& Heinle.

[51] Shor, I. \& Freire, P. (1987). A Pedagogy For Liberation. Boston: Bergin \& Garvey.

[52] Shyamlee, S. (2012). Use of technology in English language teaching and learning: An analysis. A paper presented at the 2012 International Conference on Language, Medias and Culture, Singapore.

[53] Tuan, L. (2011). EFL learners' motivation revisited. Theory and Practice in Language Studies, 1 (10), 1257-1272.

[54] van Dijk, T. (1998). Ideology._London: Sage.

[55] Warrington, S. Jeffrey, D. (2005). A rationale for passivity and de-motivation revealed: Interpretationof inventory results among freshmen English students. Journal of Language \& Learning, 3 (2), 312-335. Available at http://www.jllonline.co.uk/journal/jllearn/3_2/warrington_jeffrey.htm (accessed 2/4/2013).

[56] Williams, R. (1989). Hegemony and the selective tradition. In S. de Castell, A. Luke, \& C. Luke (Eds.) Language, authority and criticism (pp. 56-60). England: The Falmer Press.

[57] Zhao, L. (2012). Investigation into motivation types and influences on motivation: The case of Chinese non-English majors. English Language Teaching 5 (3), 100-122. Available athttp://www.ccsenet.org/journal/index.php/elt/article/view/15271 (accessed 2/4/2013).

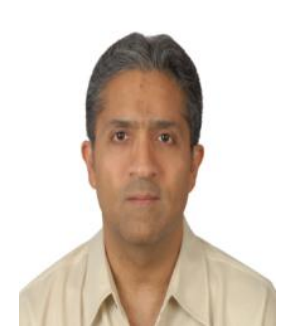

Ali S.M. Al-Issa has a Master of Arts in Education (TESOL) from University of London in, U.K. in 1993 and a Ph.D. in Education (Applied Linguistics) from University of Queensland, Australia in 2002.

$\mathrm{He}$ is an Associate Professor of Applied Linguistics at Sultan Qaboos University, Sultanate of Oman. He has presented and published widely about teaching English in Oman. His research interests include, but not limited to, teacher training and education and CLIL.

Dr. Al-Issa received the 2008 International Alumnus of the Year Highly Commended Nominee award from University of Queensland, Australia, in 2008. Dr. Al-Issa was further a recipient of the Best Researcher and Best Teacher awards at Sultan Qaboos University in 2009 and 2012 respectively. 